Jurnal Teknologi Pertanian Vol. 19 No. 2 [Agustus 2018] 117-124

Pengaruh Metode Perendaman Kedelai (Glycine max) [Puspitasari dkk]

\title{
PENGARUH METODE PERENDAMAN KEDELAI (GLYCINE MAX) TERHADAP KARAKTERISTIK PEKTIN
}

\section{The Effect of Soybean (Glycine max) Soaking Method on Characterization of Pectin}

\author{
Ivy Dian Puspitasari Prabowo*, Simon Bambang Widjanarko, Sudarminto Setyo Yuwono \\ Jurusan Teknologi Hasil Pertanian - Fakultas Teknologi Pertanian - Universitas Brawijaya \\ Jl. Veteran Malang 65145 \\ *Penulis Korespondensi: email: pii_ivy@yahoo.com
}

\begin{abstract}
ABSTRAK
Perendaman kedelai dapat mempengaruhi rendemen dan derajat esterifikasi dari pektin. Setiap industri tempe memiliki metode perendaman kedelai yang berbeda-beda. Air rendaman kedelai dan kulit ari kedelai merupakan produk samping dari industri tempe yang berpotensi sebagai bahan baku pembuatan pektin. Tujuan dari penelitian ini adalah menentukan metode perendaman kedelai yang terbaik untuk menghasilkan rendemen dan derajat esterifikasi pektin yang tinggi, sekaligus mengetahui kadar asam galakturonat. Pengujian dilakukan secara RAK (Rancangan Acak Kelompok) dengan faktor metode perendaman kedelai yaitu (1) kedelai direbus 30 menit, (2) kedelai direndam 18 jam kemudian direbus 30 menit, dan (3) kedelai direbus 30 menit kemudian direndam 18 jam. Hasil penelitian menunjukan kedelai yang direbus 30 menit kemudian direndam 18 jam merupakan perlakuan yang paling baik karena memiliki rendemen $(1.12 \pm 0.03 \%)$ dan derajat esterifikasi $(56.33 \pm 1.96 \%)$ yang paling tinggi. Pektin dari penelitian ini memiliki kadar asam galakturonat sebesar $22.45 \pm 0.84 \%$. Industri tempe dapat menerapkan penelitian ini untuk mengurangi limbah padat dan limbah cair menjadi pektin.
\end{abstract}

Kata kunci : Asam Galakturonat, Derajat Esterifikasi, Kedelai, Pektin, Rendemen

\begin{abstract}
Soaking soybean may affect the yield and degree of esterification of pectin. Each tempe industry has different soybean soaking methods. Soaking soybean water and soybean hull are a by-product of tempe industry which has potential as raw material for pectin making. The purpose of this research is to determine the best soybean soaking method to produce high yield and degree of esterification, simultaneously to determine galacturonic acid content. The experiments used RAK (Randomized Block Design) with factor of soybeans soaking method. The methods were: (1) Soybean boiled for 30 minutes, (2) Soybeans soaked 18 hours then boiled 30 minutes, and (3) Soybean boiled 30 minutes then soaked 18 hours. The results showed that soaked soybeans 30 minutes and then soaked 18 hours is the best treatment because it has the highest yield $(1.12 \pm 0.03 \%)$ and degree of esterification $(56.33 \pm 1.96 \%)$. The pectin of this soybean has $22.45 \pm 0.84 \%$ of galacturonic acid. Tempe industry can apply this research to reduce its solid and liquid waste to be pectin
\end{abstract}

Keywords : Degree of Esterification, Pectin, Physical Charateristic, Soybean, Yield 
Jurnal Teknologi Pertanian Vol. 19 No. 2 [Agustus 2018] 117-124

Pengaruh Metode Perendaman Kedelai (Glycine max) [Puspitasari dkk]

\section{PENDAHULUAN}

Industri pengolahan tempe memiliki masalah dalam penanganan limbah berupa air rendaman dan kulit ari kedelai. Kedelai memiliki 90\% kotiledon, 8\% kulit ari, dan $2 \%$ germ (Choct et al., 2010). Dinding sel kedelai mengandung $30 \%$ pektin, $50 \%$ hemiselulosa, dan 20\% selulosa (Stombaugh et al., 2000). Monsoor dan Proctor (2001) berhasil mengekstraksi $7.68-16.31 \%$ pektin dari kulit ari kedelai dan memiliki derajat esterifikasi sebesar 54-59\%. Kalapathy dan Proctor (2001) dapat mengekstraksi $18-26 \%$ pektin dari kulit ari kedelai dan memiliki derajat esterifikasi sebesar 17.09-20.79\%. Pada penelitian Monsoor (2005), ekstraksi sebesar $16.31-21.87 \%$ pektin dari kulit ari kedelai dan memiliki derajat esterifikasi sebesar 18.84-20.23\% dapat dilakukan. Pektin dapat digunakan sebagai pengental dan stabilisasi (Pinhiero et al., 2008).

Proses pembuatan tempe atara lain: perendaman kedelai dan/atau perebusan, pengupasan kulit ari kedelai, dan fementasi menggunakan Rhizopus sp. Proses perendaman kedelai merupakan proses pre-fermentasi dimana bakteri asam laktat tumbuh secara spontan (Pisol et al., 2013; Dai et al., 2017; Salakkam et al., 2017). Pra fermentasi kedelai menyebabkan penurunan $\mathrm{pH}$ menjadi 4.55.3 (Katz, 2012; Camiscia et al., 2018). Asam dapat mendegradasi protopektin menjadi pektin yang bersifat larut dalam air (Yeoh et al., 2008; Kulkarni dan Vijayanand, 2010). Rendemen pektin meningkat seiring dengan penurunan $\mathrm{pH}$ (Wai et al., 2010). Penurunan $\mathrm{pH}$ dapat menyebabkan penurunan derajat esterifikasi (Kulkarni dan Vijayanand, 2010; Wai et al., 2010; Fathi et al., 2013). Proses pemanasan dengan air juga dapat melarutkan pektin, sehingga berpeluang adanya pektin dalam air rendamam kedelai (Koubala et al., 2008; Chan dan Choo, 2013). Pektin diekstrak dari kulit ari kedelai dan pektin yang terdapat di dalam air redaman kedelai dapat diisolasi dengan proses koagulasi. Pektin dapat terkoagulasi dengan alkohol (etanol atau metanol) atau $\mathrm{Al}_{2}\left(\mathrm{SO}_{4}\right)^{2}$ (Seggiani et al., 2009). Pada penelitian ini, pektin dikoagulasi dan dipisahkan menngunakan etanol 96\%.

Tujuan dari penelitian ini adalah menentukan metode perendaman kedelai yang terbaik untuk menghasilkan rendemen dan derajat esterifikasi pektin yang tinggi, sekaligus mengetahui kadar asam galakturonatnya.

\section{BAHAN DAN METODE}

\section{Bahan}

Bahan yang digunakan untuk penelitian ini adalah kedelai yang digunakan adalah kedelai varietas Anjasmoro yang didapatkan dari Balai Penelitian Tanaman Aneka Kacang dan Umbi, Malang, Jawa Timur, Indonesia. Kulit ari kedelai diekstrak dengan menggunakan $\mathrm{HCl} 0.1 \mathrm{~N}$ "Merck" dan dikoagulasi menggunakan etanol $96 \%$ teknis.

Bahan kimia yang digunakan untuk analisis penelitian ini adalah $\mathrm{NaOH}$ p.a "Merck", Etanol p.a "Merck", indikator Phenolpthalein $1 \%, \mathrm{HCl}$ p.a "Merck", Akuades, standard D-Galacturonic acid monohydrate "Sigma", dan Trifluoroacetic acid p. A "Merck".

\begin{abstract}
Alat
Alat-alat yang digunakan untuk ekstraksi pektin adalah timbangan digital "xp1500, Jerman", erlemeyer $250 \mathrm{ml}$, saringan 40 mesh, kompor, gelas beaker $250 \mathrm{ml}$, gelas ukur $100 \mathrm{ml}$, kain saring 4 lapis, oven "Memmert", mortar, dan shaker waterbath "Julabo". Alat-alat yang digunakan untuk analisis adalah timbangan analitis "Mettler Toledo", gelas beaker $250 \mathrm{ml}$, bola hisap, corong, pipet tetes, pipet volume $10 \mathrm{ml}$, erlemeyer $250 \mathrm{ml}$, pipet ukur $10 \mathrm{ml}$, botol timbang, buret, statif, oven listrik, kertas whatman no. 42, $\mathrm{pH}$ meter "eutech", eksikator, shaker waterbath "Julabo", kertas saring kasar, centifuge, millex 0,4 $\mu \mathrm{m}$, HPLC detektor RI, dan kolom Metacarb 87C.

\section{Metode \\ Metode Penelitian}

Penelitian ini dilakukan menggunakan metode Rancangan Acak Kelompok (RAK), dengan faktor metode perendaman kedelai yaitu (1) kedelai direbus 30 menit, (2) kedelai direndam 18 jam kemudian direbus 30 menit, dan (3) kedelai direbus 30 menit kemudian direndam 18 jam. Pengujian ini diulang sebanyak lima kali.
\end{abstract}

\section{Tahap Penelitian}

1000 g kedelai kering direbus hingga matang (30 menit) sebagai perlakuan satu, kedelai yang kedelai yang direndaman 18 jam selanjutnya direbus 30 menit sebagai perlakuan kedua, dan direbusan 30 menit kemudian direndam 18 jam sebagai perlakuan ketiga.

Kedelai yang telah direndam selanjutnya dikupas kulit arinya dan diuji $\mathrm{pH}$ air 
rendaman. Kulit ari kedelai diekstrak menggunakan Shaker waterbath dan menggunakan $\mathrm{HCl}$ sebagai pelarut dengan konsentrasi 0.1 $\mathrm{N}$, rasio kedelai:pelarut 1:3, selama 45 menit, dan pada suhu $90^{\circ} \mathrm{C}$. kulit ari kedelai yang telah diekstrak dengan asam kemudian dipisahkan dari pelarutnya menggunakan saringan 40 mesh. Filtrat yang dihasilkan dan air rendaman kedelai dikoagulasi dengan menggunakan etanol 96\% dengan rasio pelarut:etanol 1:1. Pektin yang menggumpal dipisahkan dengan menggunakan kain saring 4 lapis. Pektin kemudian dilakukan pencucian sebanyak 2 kali menggunakan etanol 96\% dan disaring kembali. Selanjutnya, pektin dikeringkan menggunakan oven dengan suhu $40^{\circ} \mathrm{C}$ selama 12 jam.

\section{Tahap Pengujian}

\section{a. pH Air Rendaman Kedelai}

Kedelai yang telah direbus atau direndam kemudian diambil air rendamannya. $100 \mathrm{ml}$ air rendaman diuji $\mathrm{pH}$ dengan menggunakan $\mathrm{pH}$ meter.

\section{b. Rendemen Pektin}

Pektin yang telah dikeringkan selanjutnya ditimbang untuk mengetahui rendemen pektin yang dihasilkan. Menentukan rendemen pektin dengan menggunakan Persamaan 1.

$$
\% \text { rendemen }=\frac{\text { berat pektin yang terekstrak }(\mathrm{g})}{\text { berat kedelai }(\mathrm{g})} \times 100
$$

\section{c. Derajat Esterifikasi (Bochek et al., 2001)}

0.2 g sampel diberi $0.5 \mathrm{ml}$ etanol $96 \%$ p.a dan dilarutkan dengan $20 \mathrm{ml}$ akuades, kemudian dipanaskan $40^{\circ} \mathrm{C}$, selama 2 jam. Tambahkan 5 tetes Phenolpthalein. Sampel dititrasi dengan $\mathrm{NaOH} 0.1 \mathrm{~N}$ hingga berubah warna. Volume $\mathrm{NaOH}$ yang dibutuhkan dicatat (V1). $10 \mathrm{ml} \mathrm{NaOH} 0.1 \mathrm{~N}$ ditambahkan. Titat didiamkan selama 2 jam dalam keadaan tertutup. Sampel dicampur dengan $10 \mathrm{ml} \mathrm{HCl} 0.1 \mathrm{~N}$. Sampel dititrasi dengan $\mathrm{NaOH} 0.1 \mathrm{~N}$ hingga berubah warna. Volume $\mathrm{NaOH}$ dicatat $\left(\mathrm{V}_{2}\right)$. Penentuan derajat esterifikasi pektin dapat ditentukan dengan Persamaan 2.

Derajat esterifikasi $(\%)=\frac{v 2}{v 1+v 2} \times 100 \%$

\section{d. Kadar Asam Galakturonat (Rascón-Chu et al., 2009)}

Penentuan kadar asam galakturonat pektin tidak dilakukan pada semua perlakuan. Pengujian kadar asam galakturonat hanya dilakukan pada perlakuan yang menghasilkan pektin dengan rendemen dan derajat esterifikasi yang paling tinggi.

0.25 g sampel masukan dalam conical $50 \mathrm{ml}$, ditambahkan $4 \mathrm{~N}$ trifluoroacetic acid (TFA), dipanaskan dengan suhu waterbath $95^{\circ} \mathrm{C}$ selama 4 jam (conical tertutup), divortex selama 1 menit, kemudian di centrifuge berkecepatan $3000 \mathrm{rpm}$ selama 5 menit dan disaring menggunakan kertas saring kasar. Filtrat yang didapatkan selanjutnya dirotavapor fitrate hingga tinggal fasa $\mathrm{H}_{2} \mathrm{O}$ sebanyak $2 \mathrm{ml}$. Filtrat dipindahkan ke dalam labu ukur $5 \mathrm{ml}$ ditempatkan sampai tanda batas dengan $\mathrm{H}_{2} \mathrm{O}$, selanjutnya disaring dengan millex $0.45 \mu \mathrm{m}$. Fitrat diencerkan dengan

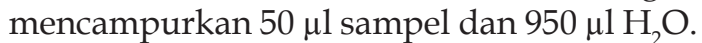
(sampel mengalami pengenceran 20x). Pencampuran $50 \mu \mathrm{l}$ standar 10000 ppm dan 950 $\mu \mathrm{l} \mathrm{H}_{2} \mathrm{O}$. Pada penelitian ini, standar mengalami pengenceran $20 x$, sehingga konsentrasi standar dalam sampel adalah 500 ppm. Sampel diinjeksikan $50 \mu \mathrm{l}$ ke HPLC, dengan kondisi setting HPLC antara lain kolom (Metacarb $87 \mathrm{C}$ ), Eluent menggunakan $\mathrm{H}_{2} \mathrm{O}$, flow sebesar $0.6 \mathrm{ml} / \mathrm{min}$, detektor (RI), serta suhu sebesar $85^{\circ} \mathrm{C}$.

\section{Analisa Data}

Data yang diperoleh dari hasil penelitian akan dianalisa secara statistik untuk mengetahui adanya perbedaan antar perlakuan dengan menggunakan uji ANOVA pada $\alpha=5 \%$ menggunakan Minitab 16. Apabila ada perbedaan, maka dilanjutkan dengan uji Tukey (BNJ) untuk menentukan nilai kritis uji perbandingan.

\section{HASIL DAN PEMBAHASAN}

\section{pH Air Rendaman Kedelai}

Pada penelitian ini menggunakan RAK (Rancangan Acak Kelompok) dengan perlakuan pertama adalah kedelai yang hanya direbus saja selama 30 menit, perlakuan kedua kedelai yang direndam 18 jam kemudian direbus 30 menit, serta perlakuan ketiga adalah kedelai yang direbus 30 menit kemudian direndam 18 jam. Pada penelitian ini kedelai 
direndam dengan air dengan perbandingan 1:3 seperti yang dilakukan oleh kebanyakan industri tempe. Perbedaan metode perendaman tersebut menyebabkan terjadinya perubahan $\mathrm{pH}$ pada air rendaman. Data $\mathrm{pH}$ air rendaman dapat dilihat pada Gambar 1.

Pada Gambar 1 dapat dilihat air rendaman dari kedelai yang direbus dahulu baru direndam memiliki $\mathrm{pH}$ yang paling rendah yaitu 4.3 , sedangkan kedelai yang hanya direbus saja memiliki $\mathrm{pH}$ paling tinggi yaitu 6.6. Perubahan $\mathrm{pH}$ pada air rendaman kedelai diduga disebabkan oleh aktivitas bakteri asam laktat. Menurut Pisol et al. (2013) jumlah bakteri asam laktat pada air rendaman kedelai dapat mencapai $9.5 \times 10^{8} \mathrm{CFU} / \mathrm{ml}$.

Kedelai yang direbus saja memiliki $\mathrm{pH}$ yang paling tinggi karena diduga belum ada aktivitas baketri asam laktat karena kondisi kedelai berada pada suhu sekitar $100{ }^{\circ} \mathrm{C}$. Pada suhu tersebut bakteri asam laktat tidak bisa tumbuh karena kondisi optimum bakteri asam laktat mesofilik pada suhu $20-30{ }^{\circ} \mathrm{C}$ dan bakteri asam laktat termofilik optimum tumbuh pada suhu $30-45^{\circ} \mathrm{C}$ (Gemechu, 2015).

\section{Derajat Esterifikasi Pektin}

Pektin dengan derajat esterifikasi diatas $50 \%$ tergolong dalam pektin metoksil tinggi, sedangkan pektin dengan derajat esterifikasi dibawah 50\% tergolong pektin metoksil rendah (Sriamornsak, 2003). Derajat esterifikasi pektin dari hasil penelitian tahap 1 antara $48.70 \%$ hingga $56.33 \%$. Data pengaruh metode perendaman terhadap derajat esterifikasi pektin dapat dilihat pada Gambar 2.

Pada Gambar 2 dapat dilihat bahwa perlakuan kedelai direbus saja dengan kedelai yang direndam, kemudian direbus memiliki notasi yang sama artinya tidak ada perbedaan nyata antara kedua perlakuan tersebut. Pada kedelai yang direbus dan direndam memiliki notasi yang berbeda artinya kedelai yang direbus dan direndam memiliki hasil derajat esterifikasi yang berbeda. Hasil penelitian ini menunjukan bahwa perlakuan kedelai yang direbus dahulu kemudian baru direndam memliki nilai derajat esterifikasi yang paling tinggi yaitu $56.33 \%$.

Kedelai yang direbus terlebih dahulu kemudian baru direndam memiliki derajat esterifikasi yang paling tinggi karena pada larutan kedelai yang direbus kemudian direndam memiliki $\mathrm{pH}$ yang paling rendah (Gambar 1) dibanding perlakuan lainnya sehingga semakin meningkatkan kelarutan pektin. Adanya asam dari larutan dapat mendegradasi protopektin menjadi pektin yaitu dengan menggantikan ion $\mathrm{Ca}^{2+}$ dan $\mathrm{Mg}^{2+}$ dari protopektin dengan ion $\mathrm{H}^{+}$dari larutan sehingga terbentuk pektin yang mudah larut (Yeoh et al., 2008). Pektin mememiliki gugus karboksil teresterifikasi, semakin banyak gugus karboksil teresterifikasi maka, semakin tinggi nilai derajat esterifikasi pektin. Pektin metoksil tinggi memiliki kelarutan tinggi pada suasana asam (Sriamornsak, 2003). Hal tersebut sesuai dengan penelitian yang dilakukan oleh Monsoor et al. (2001), semakin tinggi konsentrasi $\mathrm{HCl}$ yang digunakan maka semakin tinggi derajat esterifikasi pektin dari kulit ari kedelai.

Penelitian sebelumnya, Monsoor dan Proctor (2001) dapat mengekstraksi pektin yang memiliki derajat esterifikasi 20.79\%, Kalapathy and Proctor (2001) dapat mengekstraksi pektin yang memiliki derajat esterifikasi 59\%, dan Monsoor (2005) dapat mengekstraksi pektin yang memiliki esterifikasi $20.23 \%$. Derajat esterifikasi pektin dalam penelitian ini sesuai dengan penelitian Kalapathy dan Proctor (2001). Derajat esterifikasi penelitian ini lebih besar dari penelitian Monsoor dan Proctor (2001) serta Monsoor (2005) karena pada penelitian tersebut menggunakan $\mathrm{pH}$ larutan yang lebih rendah sehingga menghasilkan derajat esterifikasi pektin yang berbeda pula.

\section{Rendemen Pektin}

Rendemen pektin diperoleh dari mengukur persentase pektin kering yang dihasilkan dari satu kg kedelai. Rendemen pektin dari hasil penelitian antara $0.25 \%$ hingga $1.12 \%$. Perlakuan metode perendaman kedelai memiliki pengaruh terhadap jumlah rendemen pektin. Data Pengaruh Metode Perendaman terhadap Rendemen Pektin dapat dilihat pada Gambar 3.

Pada Gambar 3 dapat dilihat bahwa tiap perlakuan memiliki notasi yang berbeda. Notasi yang berbeda ini artinya setiap perlakuan memiliki hasil rendemen pektin yang berbeda nyata. Perlakuan kedelai yang direbus terlebih dahulu kemudian direndam memliki jumlah rendemen yang paling tinggi yaitu $1.12 \%$ atau dalam $1 \mathrm{~kg}$ kedelai dapat menghasilkan $11.2 \mathrm{~g}$ pektin. Rendemen pektin yang paling rendah adalah pada kedelai yang direbus saja yaitu sebesar $0.25 \%$.

Pada kedelai yang direbus dan direndam menghasilkan rendemen paling tinggi. 
Jurnal Teknologi Pertanian Vol. 19 No. 2 [Agustus 2018] 117-124

Pengaruh Metode Perendaman Kedelai (Glycine max) [Puspitasari dkk]

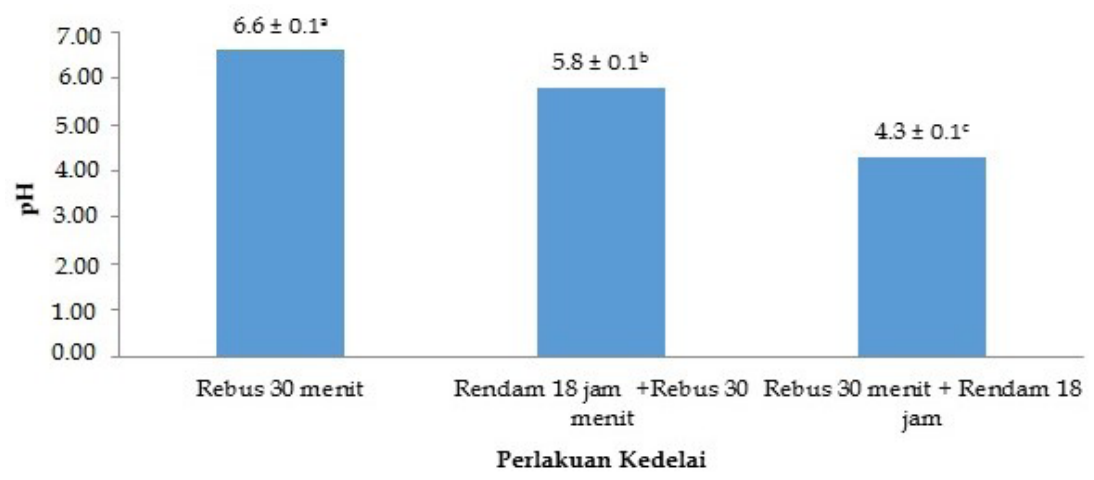

Gambar 1. Pengaruh metode perendaman terhadap $\mathrm{pH}$ air rendaman, dengan nilai rata-rata \pm standar deviasi dari lima kali ulangan

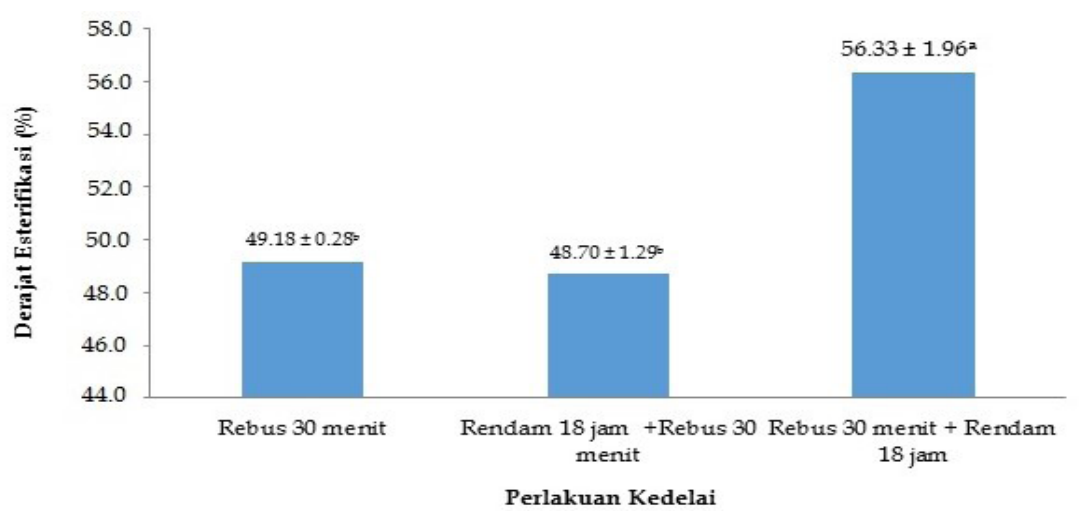

Gambar 2. Pengaruh Metode Perendaman terhadap Derajat Esterifikasi Pektin, dengan nilai ratarata \pm standar deviasi dari lima kali ulangan

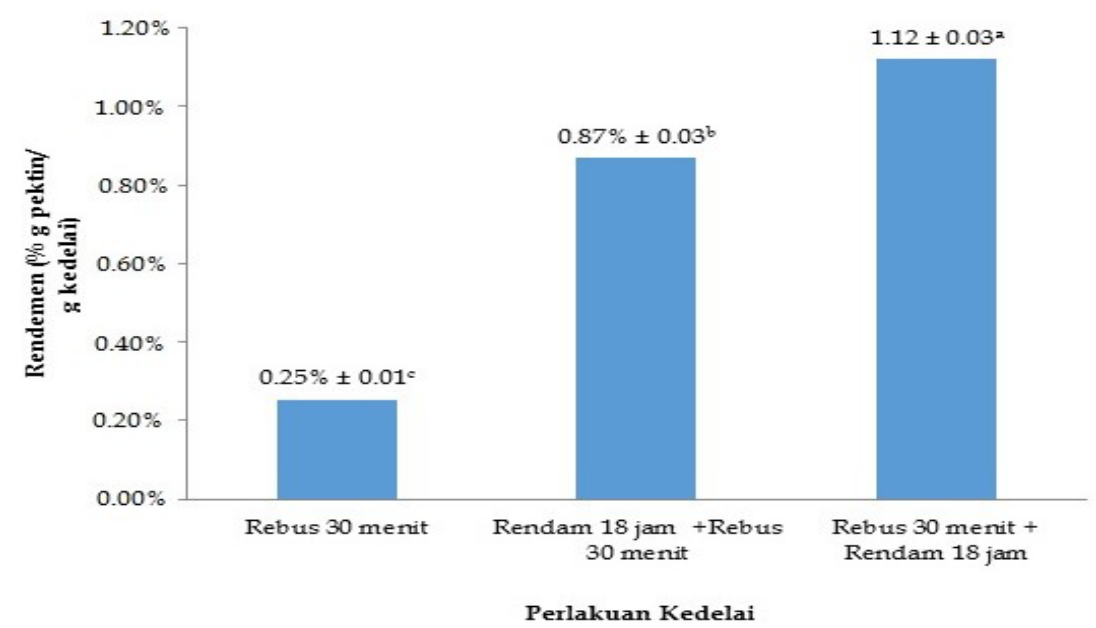

Gambar 3. Pengaruh metode perendaman terhadap rendemen pektin dengan nilai rata-rata \pm standar deviasi dari lima kali ulangan 
Kedelai yang direbus kemudian direndam mengalami penurunan $\mathrm{pH}$ hingga 4.4 (Gambar 1). $\mathrm{pH}$ yang rendah ini menunjukan banyaknya asam yang terdapat pada air rendaman kedelai. Asam yang tinggi menyebabkan semakin banyak protopektin yang terhidrolisis sehingga terbentuk pektin (Sulihono et al., 2012; Nurhikmat, 2003). Penurunan $\mathrm{pH}$ menyebabkan banyaknya ion $\mathrm{H}^{+}$yang terbentuk. Ion $\mathrm{H}^{+}$dapat menggantikan ion kalsium dan magnesium yang terdapat pada protopektin sehingga terbentuk senyawa pektin yang larut dalam air (Sulihono et al., 2012). Pada perlakuan kedelai yang direndam terlebih dahulu baru direbus memiliki $\mathrm{pH}$ larutan sebesar 58 sehingga memiliki rendemen yang tidak sebanyak kedelai yang direbus dahulu baru direndam.

Pada kedelai yang hanya direbus saja memiliki pH larutan sebesar 6.6 (Gambar 1), sehingga menghasilkan rendemen yang paling rendah, sesuai dengan beberapa penelitian mengenai pektin, misalnya ekstraksi pektin dari mangga (Wang et al., 2016; Huang et al., 2018; Oliveira et al., 2018). Rendemen pektin yang diekstraksi dengan air hanya mendapatkan rendemen sebanyak $132 \mathrm{mg} / \mathrm{g}$ sedangkan rendemen pektin yang diekstrak dengan $\mathrm{HCl} \mathrm{pH} 1.5$ memiliki rendemen sebanyak $263 \mathrm{mg} / \mathrm{g}$. Jadi, pH larutan yang rendah dapat meningkatkan rendemen pektin. Selain itu, pada perlakuan kedelai yang hanya direbus saja tidak memiliki cukup waktu kontak dengan pelarut. Waktu ekstraksi perlu diperhatikan untuk memastikan semua protopektin terhidrolisis menjadi pektin (Yujaroen et al., 2008). Penelitian yang dilakukan oleh Erika (2013) dan Hanum et al., (2012) menunjukan bahwa semakin rendah $\mathrm{pH}$ yang digunakan untuk ekstraksi, maka semakin besar rendemen pektin yang diperoleh.

\section{Pemilihan Perlakuan Tahap 1 Terbaik}

Pertimbangan pemilihan perlakuan terbaik pada penelitian ini adalah perlakuan yang dapat menghasilkan rendemen tertinggi dan derajat esterifikasi tertinggi. Perlakuan terbaik pada penelitian ini adalah perlakuan dengan merebus kedelai selama 30 menit kemudian direndam selama 18 jam. Kedelai yang direbus dahulu baru direndam menghasilkan rendemen pektin sebesar 1.12\% (Gambar 3) dan derajat esterifikasi $56.33 \%$ (Gambar 2).

\section{Kadar Asam Galakturonat}

Kadar asam galakturonat semakin tinggi menunjukkan kemurnian pektin semakin tinggi (Naqash et al., 2017; Dranca dan Oroian, 2018; Wang et al., 2018). Kadar asam galakturonat yang dihasilkan dari penelitian ini sebesar $22.45 \pm 0.84 \%$. Pada hasil penelitian ini menunjukan bahwa pektin yang dihasilkan memiliki kemurnian yang rendah, sehingga perlu dilakukan penelitian lebih lanjut untuk meningkatkan kemurnian pektin.

\section{SIMPULAN}

Hasil dari penelitian ini dapat diambil kesimpulan metode perendaman dengan cara perebusan kedelai (30 menit) kemudian direndam (18 jam) memiliki rendemen (1.12 $\pm 0.03 \%$ ) dan derajat esterifikasi (5.33 $\pm 1.96 \%$ ) yang paling tinggi dan merupakan perlakuan yang terbaik. Kadar asam galakturonat dari penelitian ini sebesar $22.45 \pm 0.84 \%$.

\section{DAFTAR PUSTAKA}

Bochek, A, M, Zabivalova, N, M, Petropavlovskii, G, A. 2001. Determination of the esterification degree of Polygalacturonic acid. Russian Journal of Applied Chemistry. 74(5):796-799

Camiscia, P, Giordano, E, D, V, Brassesco, M, E, Fuciños, P, Pastrana, L, Cerqueira, M, F, Picó, G, A, Valetti, N, W. 2018. Comparison of soybean hull pre-treatments to obtain cellulose and chemical derivatives: physical chemistry characterization. Carbohydrate Polymers. 198:601-610

Chan, S, Y, Choo, W. S. 2013. Effect of extraction conditions on the yield and chemical properties of pectin from cocoa husks. Food Chemistry. 141(4):37523758

Choct, M, Dersjant-Li, Y, McLeish, J, Peisker, M. 2010. Soy oligosaccharides and soluble non-starch polysaccharides: a review of digestion, nutritive and antinutritive effects in pigs and poultry. Asian-Australasian Journal of Animal Sciences. 23(10):1386-1398 
Dai, C, Ma, H, He, R, Huang, L, Zhu, S, Ding, Q, Luo, L. 2017. Improvement of nutritional value and bioactivity of soybean meal by solid-state fermentation with Bacillus subtilis. LWT. 86:1-7

Dranca, F, Oroian, M. 2018. Extraction, purification and characterization of pectin from alternative sources with potential technological applications. Food Research International. 113:327-350

Erika, C. 2013. Ekstraksi pektin dari kulit Kakao (Theobroma Cacao L.) Menggunakan Amonium Oksalat. Jurnal Teknologi dan Industri Pertanian Indonesia. 5(2):1-6

Fathi, B, Maghsoudlou, Y, Ghorbani, M, Khomeiri, M. 2013. Effect of pH, temperature and time of acidic extraction on the yield and characterization of pectin obtained from pumpkin waste. Journal of Food Research University of Tabriz). 22(4):465-475

Gemechu, T. 2015. Review on lactic acid bacteria function in milk fermentation and preservation. African Journal of Food Science. 9(4):170-175

Hanum, F, Kaban, I, M, D, Tarigan, M, A. 2012. Ekstraksi pektin dari kulit buah pisang raja (Musa sapientum). Jurnal Teknik Kimia USU. 1(2):21-26

Huang, B, Zhao, K, Zhang, Z, Liu, F, Hu, H, Pan, S. 2018. Changes on the rheological properties of pectin-enriched mango nectar by high intensity ultrasound. LWT. 91:414-422

Kalapathy, U, Proctor, A. 2001. Effect of acid extraction and alcohol precipitation conditions on tehe yield and purity of soy hull pectin. Food Chemistry. 73:393396

Katz, SE. 2012. The art of fermentation: an indepth exploration of essential concepts and processes from around the world. Chelsea green publishing, New York

Koubala, B, B, Mbome, L I, Kansci, G, Mbiapo, F, T, Crepeau, M, J, Thibault, J, F, Ralet, M, C. 2008. Physicochemical properties of pectins from ambarella peels (Spondias cytherea) obtained using different extraction conditions. Food Chemistry. 106(3):1202-1207

Kulkarni, S, G, Vijayanand, P. 2010. Effect of extraction conditions on the quality characteristics of pectin from passion fruit peel (Passiflora edulis f. flavicarpa L.). LWT - Food Science and Technology. 43(7):1026-1031
Monsoor, M, A. 2005. Effect of drying methods on the functional properties of soy hull pectin. Carbohydrate Polymers. 61(3):362-367

Monsoor, M, A, Proctor, A. 2001. Preparation and functional properties of soy hull pectin. Journal of the American Oil Chemists' Society. 78:709-713

Monsoor, M, A, Kalapathy, U, Proctor, A. 2001. Improved method for determination of pectin degree of esterification by diffuse reflectance Fourier transform infrared spectroscopy. Journal of Agricultural and Food Chemistry. 49(6):2756-2760

Naqash, F, Masoodi, F, A, Rather, S, A, Wani, S, M, Gani, A. 2017. Emerging concepts in the nutraceutical and functional properties of pectin-a Review. Carbohydrate Polymers. 168:227-239

Nurhikmat, A. 2003. Ekstraksi pektin dari apel lokal: optimasi $\mathrm{pH}$ dan waktu hidrolisis. Widyariset. 4:23-31

Oliveira, A, N, Paula, D, A, Oliveira, E, B, Saraiva, S, H, Stringheta, P, C, Ramos, A, M. 2018. Optimization of pectin extraction from Ubá mango peel through surface response methodology. International Journal of Biological Macromolecules. 113:395-402

Pinheiro, E, R, Silva, I, M, D, A, Gonzaga, L, V, Amante, E, R, Teófilo, R, F, Ferreira, M, M, C, Amboni, R, D, M, C. 2008. Optimization of extraction of high-ester pectin from passion fruit peel (Passiflora edulis flavicarpa) with citric acid by using response surface methodology. $\mathrm{Bi}$ oresource Technology. 99(13):5561-5566

Pisol, B, Nuraida, L, Abdullah, N, Suliantari, Khalil, K, A, 2013. Isolation and characterization of lactic acid bacteria from indonesia soybean tempe. IPCBEE. 58:32-36

Rascón-Chu, A, Martínez-López, A, L, Carvajal-Millán, E, de León-Renova, N, E P, Márquez-Escalante, J, A, Romo-Chacón, A. 2009. Pectin from low quality 'golden delicious' apples: composition and gelling capability. Food Chemistry. 116(1):101-103

Salakkam, A, Kingpho, Y, Najunhom, S, Aiamsonthi, K, Kaewlao, S, Reungsang, A. 2017. Bioconversion of soybean residue for use as alternative nutrient source for ethanol fermentation. Biochemical Engineering Journal. 125:65-72 
Jurnal Teknologi Pertanian Vol. 19 No. 2 [Agustus 2018] 117-124

Pengaruh Metode Perendaman Kedelai (Glycine max) [Puspitasari dkk]

Seggiani, M, Puccini, M, Pierini, M, Giovando, S, Forneris, C. 2009. Effect of different extraction and precipitation methods on yield and quality of pectin. International Journal of Food Science \& Technology. 44(3):574-580

Sriamornsak, P. 2003. Chemistry of pectin and its pharmaceutical users: a review. Silpakorn University International Journal. 3:206-228

Stombaugh, S, K, Jung, H, G, Orf, J, H, Somers, D, A. 2000. Genotypic and environmental variation in soybean seed cell wall polysaccharides. Crop Science. 40(2):408-412

Sulihono, A, Tarihoran, B, Agustina, T, E. 2012. Pengaruh waktu, temperatur, dan jenis pelarut terhadap ekstraksi pektin dari kulit jeruk bali (Citrus maxima). Jurnal Teknik Kimia. 18(4):1-8

Wai, W, W, Alkarkhi, A, F, Easa, A. M. 2010. Effect of extraction conditions on yield and degree of esterification of durian rind pectin: an experimental design. Food and Bioproducts Processing. 88(2):209-214
Wang, M, Huang, B, Fan, C, Zhao, K, Hu, H, Xu, X, Pan, S, Liu, F. 2016. Characterization and functional properties of mango peel pectin extracted by ultrasound assisted citric acid. International Journal of Biological Macromolecules. 91:794-803

Wang, W, Chen, W, Zou, M, Lv, R, Wang, D, Hou, F, Feng, H, Ma, X, Zhong, J, Ding, T, Ye, X, Liu, D. 2018. Applications of power ultrasound in oriented modification and degradation of pectin: A review. Journal of Food Engineering. 234:234:98-107

Yeoh, S, Shi, J, T, Langrish, T, A, G. 2008. Comparisons between different techniques for water-based extraction of pectin from orange peels. Desalination. 218:229-237

Yujaroen, P, Supjaroenkul, U, Rungrodnimitchai. 2008. Extraction of pectin from sugar palm meat. Thammasat Int. J. Sc. Tech. 13:44-47 